\title{
Revolusi Dunia Bisnis Indonesia Melalui E-Commerce dan E-Business: Bagaimana Solusi Hukumnya
}

\author{
Nindyo Pramono
}

\begin{abstract}
The activities of electronic trade have brought about revolution in the business world, such as the emergence of e-commerce and e-business. Yet, the impact of such activities have resulted in various legal problems. This writing tries to explore some growing problems and solutions being offered from the impact of e-commerce and e-business development.
\end{abstract}

\section{Pendahuluan}

Era baru dunia bisnis Indonesia saat ini sedang memasuki era e-commerce atau ebusiness atau transaksi Telematika. E-business tampaknya merupakan genus dari e-commerce. E-commerce masih terbatas pada transaksi dagang saja, maka untuk e-business sudah menjangkau pada sasaran lebih luas lagi. Obyeknya sudah menyangkut banyak jenis barang komoditi seperti garmen, buku, $C D$ dan VCD, bunga, kartu ulang tahun, parfum dan sebagainya.' Bahkan bagi dunia ilmu pengetahuan, E-Book atau Buku Elektronik akan menjadi buku masa depan. Masa yang akan datang, bisnis buku offline akan digantikan dengan model online. ${ }^{2}$

Bisnis teknologi informasi seperti ini memang memberikan angin segar bagi para pelakunya. Indonesia dengan jumlah penduduk yang sangat banyak dan letak geografis yang spesifik sebagai archipelago state menjadi daya tarik tersendiri bagi dunia e-commerce dan e-business. ${ }^{3}$ New Economy memang bukan sekedar internet. Namun, internet telah menjadi kendaraan menuju ke sana. Di era baru itu, inovasi teknologi menjadi faktor penting yang menentukan pertumbuhan

'HP Panggabean. 2000. "Pembentukan Hukum dalam Transaksi E-Commerce." Artikel dalam Newsletter No. 42/IX/September/2000. Jakarta.

${ }^{2}$ Warta Ekonomi. Tanggal 19 Maret 2001

${ }^{3}$ Warta Ekonomi. Tanggal 22 Januari 2001 
ekonomi di samping faktor modal atau investasi dan tenaga kerja. ${ }^{4}$ Indriantoro ${ }^{5}$ mengatakan bahwa perkembangan e-commerce dan e-business lebih luas dari sekedar teknologi informasi dan internet. Semua perusahaan merasa perlu untuk membuat web site, kemudian sudah merasa puas dan merasa sudah ikut dalam hype yang bernama e-commerce dan e-business. Demikian pula manfaat teknologi informasi dalam manajemen operasional mulai banyak perusahaan besar seperti Ace Hardware, Garuda Indonesia, bahkan di dunia Pasar Modal, transaksi saham sudah mulai menggunakan teknologi telematika ini. Penghematan biaya transaksi mulai terbukti dan teknologi informasi melalui. jaringan internet ini bisa menekan angka kerugian perusahaan. ${ }^{6}$ Bahkan menurut Bajaj? sejumlah keuntungan pemanfaatan e-commerce adalah penghematan waktu, tidak akan ada delay sebagai akibat kendala transportasi, mengeleminasi kemungkinan error dalam ketik pesan dan sebagainya, menunjang efektivitas dan efisiensi perusahaan, penghematan biaya advertizing, marketing, dan pelayanan yang lebih luas terhadap konsumen.

Dari semua liputan seperti dikemukakan di atas menunjukkan bahwa saat ini dunia bisnis memang benar-benar telah memasuki era baru yang disebut e-commerce atau e-business atau transaksi telematika. Tampaknya ramalan Naisbitt ${ }^{8}$ yang mengatakan bahwa era global saat ini telah menyajikan suatu pandangan dunia baru yang ditandai dengan era elektronika benar-benar menjadi kenyataan. Orang mulai ingin bersatu untuk berbisnis secara jauh lebih bebas, mereka ingin bebas secara politik dan budaya. Tidak akan ada penyatuan Eropa yang sebenarnya. Tidak akan ada mata uang bersama, yang ada justru akan terjadi banyak mata uang di dunia. Mata uang bersama yang ada hanyalah elektronik. Tidak akan ada kebutuhan mata uang yang lain. Demikian Naisbitt meramalkan. Namun, dari semua paparan itu ironisnya' masalah utama yang dihadapi Indonesia bukan pada teknologinya, tetapi justru pada regulasinya. ${ }^{9}$ Khusus bagi kalangan teoritisi hukum, banyak yang masih buta tentang era baru dunia bisnis yang disebut e-commerce dan e-business ini.

Sementara itu, praktik e-commercè dan ebusiness sudah jauh lebih maju ke depan dan telah menimbulkan banyak dampak yuridis yang belum terjangkau oleh perangkat hukum yang ada. Memang itulah kenyataan yang terjadi di Indonesia, hukum selalu "ketinggalan"

4 Warta Ekonomi. Tanggal 8 Januari 2001.

${ }^{5}$ Nur Indriantoro. 2000. "Perkembangan E-Commerce dan E-Business Lebih luas dari Sekedar Tehnologi Informasi atau Internet." Makalah. Fakultas Ekonomi. UGM. Yogyakarta.

${ }^{6}$ Warta Ekonomi. Tanggal 12 Februari 2001.

${ }^{7}$ Kamlesh. KBajaj dan Nebjani Nag. 2000. Elektronic Commerce The Cutting Edgeof Business. Tata McGrawHill Publishing Company Limited. New Delhi.

${ }^{8}$ Naisbitt, John. 1994. Global Paradok: The Bigger the World Economy, the More Powerful Its Smallest Players. New York. USA: William Morrow and Co. Inc.

${ }^{9}$ Warta Ekonomi . Tanggal 8 Januari 2001. 
atau "ditinggalkan" oleh kemajuan ekonomi atau bisnis. Bisnis tidak bisa menunggu hujan baru membeli payungnya, sehingga inovasi bisnis sering tidak terjangkau oleh aturan hukum yang harus melingkupinya. Akibat ekses bisnis yang berpotensi menimbulkan crime, belum dijangkau oleh aturan hukum yang memadai, sehingga aparat penyidik menjadi kesulitan untuk melakukan proses penyidikan cybercrime. Modus utama cybercrime yang sering terjadi di Indonesia antara lain penyalahgunaan kartu kredit milik orang lain di internet, creckering, dan pengiriman virus ke pihak lain. Bahkan Romzy Alkaterie, Wakil ketua bidang informatika Kadin, menjelaskan, Bahwa penyalahgunaan kartu kredit milik orang lain di internet merupakan kasus cybercrime terbesar yang berkaitan dengan dunia bisnis di Indonesia. ${ }^{10}$

\section{Permasalahan Hukum dalam E-Com- merce dan E-Business}

Seperti dikemukakan di atas, bagi kalangan ahli hukum di indonesia yang hukumnya masih berkiblat kepada sistem hukum Eropa Kontinental, khususnya yang berkaitan dengan aspek perjanjian atau transaksi bisnis, transaksi telematika masih menyimpan beberapa persoalan hukum yang sangat substansial dan krusial. Transaksi telematika merupakan transaksi yang lingkup kerjanya menggunakan media elektronika atau internet. Media ini merupakan media yang tidak real seperti halnya transaksi-transaksi bisnis yang konvensional. Dari segi proses dan mekanisme terjadinya transaksi dapat dikemukakan beberapa permasalahan hukum sehubungan dengan masalah hukum perjanjian antara lain sebagai berikut:"

1. Masalah saat kapan terjadinya atau lahirnya kesepakatan dalam transaksi telematika. Permasalahan ini erat kaitannya dengan saat bertemunya permintaan dan penawaran melalui media maya tersebut. Pesan atau permintaan dilakukan melalui internet dan jawaban juga demikian. Kapan saat pesanan dan jawaban pesanan itu terjadi? Pada saat terjadi di-clik melalui simbol-simbol dalam di internet tersebut atau saat lain yang dapat dikualifikasikan secara yuridis sebagai saat lahirnya perjanjian. Tidakkah perlu adanya konfirmasi dari pihak pemesan atau pembeli? Sementara isi pesan yang disampaikan melalui' internet dapat diubah atau diganti oleh orang lain. Secara konvensional, perjanjian lahir, terjadi, timbul, dan bahkan berlaku segera setelah terjadi kesepakatan antara para pihak. Demikian menurut Pasal 1320 ayat (1) KUHPerdata Indonesia. Sementara salah satu pihak dalam transaksi

${ }^{10}$ Warta Ekonomi. Tanggal 5 Maret 2001.

"M Arsyad, Sanusi. 2000. "Transaksi Bisnis Dalam Electronic Commerce (E-Commerce) Studi tentang Permasalahan-permasalahan Hukum dan Solusinya." Tesis S2. Tidak dipublikasikan. Magister Hukum UII. Yogyakarta. HIm... Lihat juga Budi Agus Riswandi. 2001. "Perlindungan Hukum terhadap Nasabah Dalam Transaksi Pembayaran E-Banking (Studi Atas Sistem Pembayaran Internet Berbașis SET)." Tesis S2. Tidak dipublikasikan. Magister Hukum Ull. Yogyakarta. Lihatjuga Panggabean. Op. Cit. 
3.. Crelematika bèrada'di negaraclain. ir 'tesi: Apakah Pasāl:1320 ayat (1) KüHPerdata

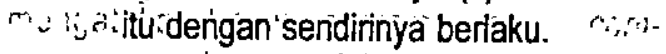

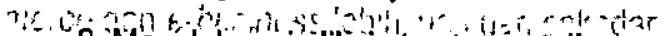
2. Masalah yurisdiksi atau tempat dimana

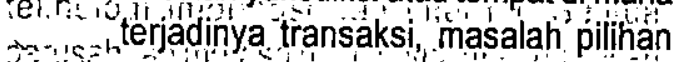
sii ? hưkum atau pilitan hakim dan masalah si ? is pembuktian , Transaksi bisnis melalui $m=$ media internet atau telematika tidak men me menjeláskăn tempat di mäna transäksi itu terjadi Hali ini sangat peñting secara man ajujuridis karéna berkaitan dengán perusal yurisdiksi pengadilan yang berwenang Vilimbul sengketa dan masalah pilihan , hukum (chôse of law atau aplicable law) PE in serta masalah pembuktian. Oleh karena dan " itui, kebanyakan transaksi telematika dilakukan oleh pihak yang berada pada pen yurisdiksi hukum negàra yang berbeda, s? י m pada saat kesepakatan secara online $x^{\prime}=$; id dibuat tidak secara tegas dan jelas me-menunjuk man atau memuat klausul pesen o hukum négara atau hakim manaka id. r yang berwenang mengadili, jika kemudian hari menjjadi sengketa. Masalah îni dapat dikaji melalui hukum

pérdata Internasional (HPI). Namü demikian, tidak semua hakim Indonesia paham benar dengan _..... seluk beluk - HPI dan penyelesaian - $k$ melaluij, HPI, sendiri,tidak, sepenuhnya

- 'dapat memuaskan justisiabelen dari nizrroskalangan bisnis.

3.Masalán yang làin masih berkaitan - - s : dengan keabsahan transaksi. Bagaimana melacaknya jika transaksi dibuat

$5: \therefore$ oleh orang yang di bawah umur atau. $\therefore$ orangiyang mempunyai maksud jahat?

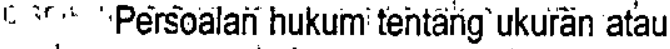

th kniteria dibawah umur pun berbeda-

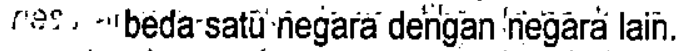
"r. $\epsilon_{i \prime}$ :!n könvensional mengatur' selama

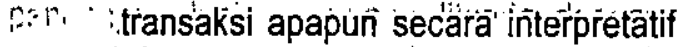
$\because \quad$ :termasuk transaksi telemátika - telàh $\therefore$ memenuhi syarat sahnya perjanjian $\therefore$ :seperti diatur di dalam. Pasal 1320 ngın ir KUHPerdatä, maka-tidak ada alāsàn

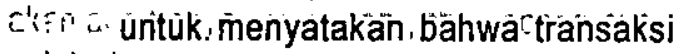

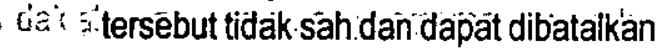

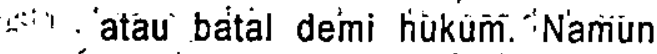
'ت ' demikian, dari sini pun màsih dapat e.:! 'J dipermäsalahkañ lebih"lanjüt; apakah

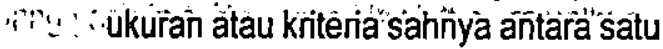
- ar., negara dengan negarà lain itu sama:

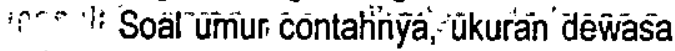

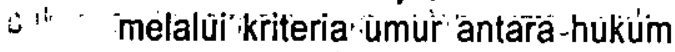
$\rho^{\prime} \rho_{1}=$ Eropa "dengan "hukum 'perkâwinān

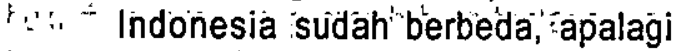
dibandingkan dèngàn hukum àdat. $u=r$ : Lalu; mana yang harus dipakai untuk mènentukan keabsâthân trànsàksi berdásarkan kriteria syarat "kecakapan . "ir "meläkukan perbuátan hukum" dari

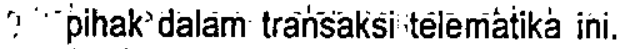
in : Secara yuridis másih berpotensi debat-

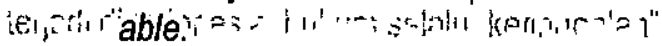

4. Masalah keabsahan digital signature dan data message. Apakah tanda tangan digital dapat diakui secara

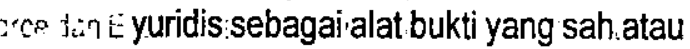
C. Y Y dapat dikatakan sebagai data asli atau sebagai tulisan asli. Masalah data message erat kaitannya dengàn confidentiality, integrity dan authenticity dari pihak pemesan." Bägaimanakah memastikan bahwa data pesan yang 
sangat erat kaitannya dengan privacy pemesan, confidentiality pemesan dan pesanan, integrity dan authencity, benar-benar data asli yang disepakati dan diakui oleh pihak pemesan? Hukum pembuktian di Indonesia sampai saat ini belum menjangkau.

\section{Solusi Hukum dalam E-Commerce dan E-Business}

Secara konvensional barangkali dapat dijadikan rujukan untuk menangani kasus ecommerce dan e-business yang mungkin terjadi di Indonesia adalah: ${ }^{12}$ (1). KUHP tentang persaingan curang; (2) KUHPerdata: Pasal 1313 tantang pengertian perjanjian, Pasal 1320 tentang syarat sahnya perjanjian, Pasal 1338 tentang asas-asas pokok dalam perjanjian, Pasal 1321, 1323, 1324, 1325, 1326 , 1327,1328 tentang pembatalan perjanjian dan alasan-alasannya (dwang, dwaling, bedrong), Pasal 612,613 tentang cara penyerahan barang bergerak dan piutang-piutang atas -nama dan atas tunjuk. Di samping itu telah diundangkan beberapa Undang-undang yang melibatkan persoalan e-commerce dan e-business yaitu UU PT, UU Pasar Modal, UU Anti Monopoli, UU Perlindungan Konsumen dan UU Telekomunikasi. Saya menambahkan masih ada satu rujukan lagi UU Dokumen Perusahan.
Hukum konvensional ini tampaknya tidak seluruhnya menjangkau atau dapat dijadikan solusi untuk mengatasi masalah-masalah hukum yang mungkin timbul sehubungan dengan transaksi telematika ini. Permasalahannya begitu perkara diajukan ke depan hakim, menurut sistem hukum Indonesia (UU Pokok Kehakiman) hakim tidak boleh menolak dengan alasan tidak ada hukumnya. (ius curia novit). ${ }^{13}$ hakim harus mencari hukumnya karena pada dasarnya hakim adalah penemu hukum (rechtsvinder). Untuk menemukan hukum, ia harus belajar tentang perkembangan hukum yang hidup dan tumbuh di masyarakat. Dalam bisnis telematika, maka masalah cyberlaw yang berkembang di sistem Anglo Amerika mau tidak mau harus dipelajari. Tidak mustahil kontrak berdasarkan praktik yang terjadi di Amerika dan Inggris akan berpengaruh pada hukum kontrak di negara yang berjuridiksi Civil Law atau Eropa Kontinental, seperti Indonesia. ${ }^{14}$ Secara Internasional United Nations Commision on Internasional Trade law (UNCITRAL) telah'membuat Model Law yang dapat dipakai sebagai rujukan dalam kontrak dagang internasional melalui e-commerce dan e-business. Satu kelebihan dari Belanda sebagai negara yang pemah menjajah Indonesia dan memberikan peninggalan model Eropa yang sampai sekarang masih banyak adalah pengaruh American System tersebut cepat diadopsi ke dalam kodifikasi hukum mereka,

\footnotetext{
${ }^{12}$ Panggabean. Op. Cit.
}

${ }^{13}$ Sudikno Mertokusumo. 1999. Hukum Acara Perdata. Yogyakarta: Liberty.

${ }^{14}$ Newsletter No. 24 Septenber 2000.

${ }^{15}$ Pramono, Nindyo. 1997. Kesiapan Instrumen Hukum Pasar Modal Indonesia Dalam Menghadapi Pasar Bebas. Makalah. Tidak dipublikasikan. Yogyakarta. B. Smallen.de.. 1995. Effecten beurs. Effecten bedriff en effecten verkeen. JH. De Bussy. BV: Amsterdam. 
sehingga hukum selalu mampu berfungsi sebagai a tool of social engineering di sana. ${ }^{15}$ Namun menurut hemat saya masih merupakan perjalanan yang cukup panjang untuk menjadikan setiap hakim Indonesia memahami era baru bisnis global melalui $e$ commerce dan e-business ini.

Dalam hubungannya dengan masalah pembuktian, menurut hukum Indonesia, masalah pembuktian diatur di dalam HIR dan Rbg. Alat bukti dalam perkara perdata dimulai: (1) alat bukti tulisan; (2) alat bukti saksi; (3) persangkaan; (4) pengakuan; (5) sumpah. Dalam kaitannya dengan digital signature dalam e-commerce dan e-business tampaknya digital signature ini tidak masuk dalam kategori alat bukti konvensional tersebut. Lalu bagaimana solusinya, jika seandainya hakim Indonesia menghadapi kasus e-commerce dan e-business seperti ini. Melalui metode penemuan hukum hakim dapat belajar dari pandangan Saragih seperti dikutip Panggabean. Saragih ${ }^{16}$ mengemukakan solusi penanganan kasus yang berkaitan dengan masalah pembuktian di pengadilan sebagai berikut. Bahwa dengan US Statute of Frauds yang sudah berusia 300 tahun, para pihak tidak dapat memperkarakan suatu kontrak dalam sidang pengadilan manakala mereka tidak memiliki bukti-bukti yang substansial yang mengakui adanya kontrak. Ketentuan dari Statute of Frauds tampaknya belum membuka peluang bagi sahnya perjanjian dari electronic contract seperti transaksi telematika ini. Pemahaman hukum yang standar, ciri fisik yang khas dari kertas dan tanda tangan dengan tinta atau pulpen memungkinkan ahli forensik menentukan keaslian atau keabsahan dari secarik kertas dokumen, sebaliknya dokumen elektronik tidak dapat dijadikan sebagian dokumen yuridis. Namun dalam kenyataannya, hakim Amerika talah menerapkan penyimpangan dari ketentuan Statute of Frauds tersebut, kemudian mengembangkan pertimbangan hukum dan memutuskan bahwa sebuah kontrak menjadi dapat dilaksanakan sepanjang para pihak mengakui keberadaan kontrak dimaksud, meskipun dokumen itu tanpa adanya tanda tangan. Sebagai contoh, Mahkamah Agung negara bagian Nebraska tahun 1965 memperkenankan sebuah perusahaan asuransi menyampaikan pembukuan mengenai pembayaran perusahaan yang telah dibuat dan tersimpan baik dan rapi dalam komputer. Pembukuan dalam komputer adalah dokumen yang dapat diandalkan mengingat data processing control-nya dapat ditelusuri dan diuji dalam sistem komputer.

Memang masalah digital signature masalahnya tidak sederhana. Antara tanda tangan konvensional dengan tanda tangan digital bukan hanya sifatnya yang berbeda, tapi juga bentuknya. Secara konvensional wujudnya tanda tangan biasa dengan tinta atau pulpen dan sebagainya yang lazim dikenal di masyarakat, sementara tanda tangan electronic berupa kode-kode matematik dengan menggunakan program tertentu dengan keykey tertentu pula. Arsyad dengan mengacu pada pendapat Macculaagghi, Peter Little dan William Caeli (2000) memberikan solusi mengenai masalah tanda tangan ini sebagai

\footnotetext{
${ }^{16}$ Newsletter No. 24 September 2000.

${ }^{17}$ M. Arsyad Sanusi. Op. Cit.
} 
berikut. Menurutnya tanda tangan secara umum harus mampu menjalankan sejumlah fungsi, yaitu ia dapat: ${ }^{17}$ (1) mengidentifikasi penandatanganan; (2) memberikan kepastian atas terlibatnya seseorang dalam penandatanganan itu; (3) mengasosiasikan orang tertentu dengan isi dokumen; (5) menyatakan niat seseorang untuk diikat dengan isi dokumen; (5) menyatakan kepemilikan dokumen itu pada penandatanganan itu; (6) menyatakan beberapa kesepakatan tertulis yang dimungkinkan ditulis oleh pihak ketiga yang bukan merupakan pihak yang terlibat dalam kesepakatan yang mengikat. Jika fungsi seperti dikemukakan di atas dapat dipakai sebagai kriteria untuk menilai sah tidaknya tanda tangan digital, maka tidak ada alasan untuk menolak tanda tangan digital sebagai tidak sah jika unsur atau kriteria tersebut di atas dipenuhi. Masalah berikutnya adalah bahwa tanda tangan elektronik sesuai dengan karakternya, mengambil bentuk fisik yang lebih berdimensi metafisik daripada konkret seperti yang ada pada tanda tangan tradisional.

Selanjutnya Arsyad (2000) mengemukakan sebagai komparasi kedua macam tanda tangan itu berikut adalah 7 (tujuh) karakteristik fisik tanda tangan tradisional: (1). Dapat dibuat secara mudah oleh orang yang sama; (2). Secara mudah dapat dikenal oleh pihak ketiga; (3). Relatif sulit untuk dipalsu oleh pihak ketiga; (4). Diikat dan disertakan dalam dokumen sehingga menjadi satu kesatuan; (5). Melibatkan proses fisik dari tinta.ke kertas; (6). Secara komparatif standar untuk semua dokumen yang ditandatangani oleh orang yang sama; (7). Relatif sulit untuk dihapus tanpa adanya bekas. Jika yang menjadi referensi untuk mengukur suatu keabsahan tanda tangan digital adalah ciri-ciri fisik seperti tersebut di atas,maka tanda tangan digital harus ditolak' keabsahannya. Namun perkembangan teknologi telematika jelas telah mampu menyajikan bentuk-bentuk tanda tangan digital seperti dalam e-commerce dan e-business. Bagi Indonesia yang sampai saat ini belum mempunyai cyberlaw dan sejenisnya, sekarang solusi hukum yang dapat diharapkan tinggal kepada hakim yang menangani perkara e-commerce dan 'e-business. Berani atau tidak hakim membuat yurisprudensi melalui doktrin seperti ini, dengan belajar dari hukum asing yang sudah lebih maju. Harus diakui bahwa hukum Amerika sekarang ini memang mendominasi pembaharuan hukum Indonesia dan memang itulah strategi Amerika. Transfer skill, knowledge and technology Amerika harus dibarengi dengan transfer hukumnya. Itu maunya Amerika. Tidak ada salahnya, sebelum Indonesia mempunyai cyberlaw atau model law atau UU yang berkaitan dengan jasa internet termasuk e-commerce dan e-business, hakim dapat belajar dari negara maju dan menjadi pembuat hukum di forum pengadilan. Bagi indonesia yang menganut sistem hukum Eropa Kontinental, hukum asing diakui sebagai hukum, bukan sekedar fakta seperti pandangan hakim Amerika. Jika hukum asing adalah hukum menurut sistem hukum Indonesia, maka tidak ada keberatannya hakim menerapkan atau mengadopsi hukum asing tersebut yang diberlakukan melalui putusan hakim di Indonesia.

Selanjutnya yang berkaitan dengan masalah peralihan data riil atau data fisik atau dokumen fisik suatu perusahaan ke data elektronik, Indonesia sebenarnya sudah mempunyai UU yang berkaitan dengan 
masalah itu yaitu UU Dokumen Perusahaan. Menurut UU No. 8 Tahun 1997, dokumen perusahaan dapat dialihkan ke dalam microfilm atau media lainnya. Pengalihan tersebut dapat dilakukan sejak dokumen dibuat atau diterima oleh perusahaan dan harus dilegalisasi. Cara pengalihannya harus dibuatkan berita acara untuk itu yang sekurang-kurangnya memuat: (1) keterangan tempat, hari, tanggal, bulan dan tahun dilakukannya legalisasi; (2) keterangan bahwa pengalihan dokumen perusahaan yang dibuat di atas kertas ke dalam micro film atau media lainnya telah dilakukan sesuai dengan aslinya; (3) tanda tangan dan nama jelas pejabat yang bersangkutan. Print out dari dokumen yang sudah dialihkan ke dalam micro film atau media lain tersebut berlaku sah sebagai alat bukti. Menjadi, pertanyaan sekarang, apakah digital signature dan data message tersebut dapat dijangkau oleh UU Dokumen Perusahaan. Apakah data tersebut dapat dikualifikasikan sebagai dokumen perusahaan. Menurut Pasal 1 ayat (2) UU No. 8 Tahun 1997 yarig dimaksud dengan dokumen perusahaan adalah data, catatan dan atau keterangan yang dibuat dan atau diterima oleh perusahaan dalam rangka pelaksanaan kegiatannya, baik tertulis maupun perekam dalam bentuk corak apapun yang dapat dilihat.

\section{Simpulan}

Dengan kehadiran aktivitas perdagangan elektronik telah terjadi revolusi di dunia bisnis. Semula kegiatan bisnis banyak mengandalkan pada penggunaan kertas, dengan adanya e-commerce dan e-business, maka kegiatan bisnis telah beralih pada kegiatan yang sifatnya paperless. Akibat lebih jauh dari revolusi di dunia bisnis yang disebabkan oleh aktivitas e-commerce dan ebusiness, hal ini telah banyak memunculkan pelbagai permasalahan hukum. Permasalahanpermasalahan itu di antaranya berkaitan dengan privacy pemesan, confidentiality pemesan dan pesanan, integrity dan authencity, keabsahan digital signature, serta banyak lagi yang lainnya.

Solusi hukum yang ditawarkan terhadap perkembangan e-commerce dan e-business dapat dilakukan dengan beberapa pendekatan. Pendekatan itu dapat dengan cara mengoptimalkan sistem hukum konvensional, keduanya melakukan pembuatan hukum baru yang mengatur masalah e-commerce, dan ketiganya dapat dengan cara menggabungkan dari dua pendekatan satu dan dua.

\section{Daftar Pustaka}

Arsyad, Sanusi.M. 2000. "Transaksi Bisnis Dalam Electronic Commerce (E-Commerce) Studi tentang Permasalahanpermasalahan Hukum dan Solusinya." Tesis S2. Tidak dipublikasikan. Magister Hukum UII. Yogyakarta.

Bajaj, Kamlesh. K dan Nebjani Nag, 2000. Electronic Commerce The Cutting Edge of Business. Tata McGrawhill Publishing Company Limited. New Delhi.

Direktorat Jenderal Hukum dan Perundangundangan. Departemen Kehakiman. 1998. Sejarah Pembentukan UU RI No. 8 tahun 1997 Tentang Dokumen Perusahaan. Jakarta.

Indriantoro, Nur. 2000. "Perkembangan ECommerce dan E-Business Lebih luas 
dari Sekedar Tehnologi Informasi atau Internet." Makalah. Fakultas Ekonomi. UGM. Yogyakarta.

Maccullaghi, Adrian Peter Little dan William Caeli. Electronic Signature: Understanding thePast to Decelop the Future. UNSW Law Journal, di http:/ www.unsw.com.au/lawjournal.html.

Naisbitt, John. 1994. Global Paradok: The Bigger the World Economy, the More Powerful its Smallest Players. William Morrow and Co. Inc. New York, USA.

Panggabean, HP. 2000. "Pembentukan Hukum Dalam Transaksi E-Commerce." Artikel dalam Newsletter No. 42/IX/September/2000. Jakarta.

Pramono, Nindyo. 1997. Kesiapan Instrumen Hukum Pasar Modal Indonesia Dalam Menghadapi Pasar Bebas. Makalah. Tidak dipublikasikan. Yogyakarta.
. 1997. Sertifikat Saham PT Go Publik dan Hukum Pasar Modal di Indonesia. PT. Citra Aditya Bakti. Bandung.

Riswandi, Budi Agus. 2001. "Perlindungan Hukum Terhadap Nasabah Dalam Transaksi Pembayaran E-Banking (Studi Atas Sistem Pembayaran internet Berbasis SET)." Tesis S2. Tidak dipublikasikan. Magister Hukum Uli. Yogyakarta.

Smallen.de.B,. 1995. Effecten beurs. Effecten bedriff en effecten verkeen. JH. De Bussy. BV. Amsterdam.

PPH Newsletter. No. 42 September 2000.

Warta Ekonomi No. 01/XII/8 Januari 2001.

Warta Ekonomi No. 03/XII/22 Januari 2001.

Warta Ekonomi No.06/XII/12 Februari 2001.

Warta Ekonomi No.09/Xil/5 Maret 2001

Warta Ekonomi No.11/XII/19 Maret 2001.

Info bank, No.257 Vol. XXII Januari 2001. 